\title{
Article \\ Effectiveness of Electricity-Saving Communication Campaigns: Neurophysiological Approach
}

\author{
Anna Borawska *, Mariusz Borawski and Małgorzata Latuszyńska (D)
}

check for updates

Citation: Borawska, A.; Borawski, M.; Łatuszyńska, M. Effectiveness of Electricity-Saving Communication Campaigns: Neurophysiological Approach. Energies 2022, 15, 1263. https://doi.org/10.3390/en15041263

Academic Editor: Dimitrios

Katsaprakakis

Received: 5 January 2022

Accepted: 7 February 2022

Published: 9 February 2022

Publisher's Note: MDPI stays neutral with regard to jurisdictional claims in published maps and institutional affiliations.

Copyright: (C) 2022 by the authors. Licensee MDPI, Basel, Switzerland. This article is an open access article distributed under the terms and conditions of the Creative Commons Attribution (CC BY) license (https:// creativecommons.org/licenses/by/ $4.0 /)$.
Institute of Management, University of Szczecin, 71-004 Szczecin, Poland; mariusz.borawski@usz.edu.pl (M.B.); malgorzata.latuszynska@usz.edu.pl (M.Ł.)

* Correspondence: anna.borawska@usz.edu.pl

\begin{abstract}
Public communication campaigns are among the tools for promoting electricity saving. A crucial task in the process of creating a campaign is to design a simple message to effectively reach the average consumer. It is a beneficial practice to create alternative messages and pretest them to find the most effective. The research methodology during pretesting includes both quantitative and qualitative methods. However, it is believed that the outcomes obtained with the use of conventional techniques are not fully reliable. Therefore, the following question arises: What additional research methods should be applied at the stage of testing the message of a communication campaign so that its effectiveness can be assessed more reliably and/or improved even before its broadcast? In this study, we aim to present the possibility of applying cognitive neuroscience methods in conjunction with a questionnaire to experimentally check the effectiveness of the message using the example of selected electricity-saving communication campaigns. The key results of this study indicate that merging conscious and subconscious reactions to media messages allows us to gain new knowledge that can be used in the future to improve the communication campaign effectiveness. Our investigation showed the benefits that can be obtained by synergizing traditional research methods with neuroscientific approaches.
\end{abstract}

Keywords: electricity saving; public communication campaign; media message effectiveness; cognitive neuroscience; EEG

\section{Introduction}

Saving electricity has an economic and ecological dimension. It allows for a reduction in expenses incurred by electricity recipients. However, it also means a lower consumption of energy resources and, thus, less environmental damage resulting from the combustion of fossil fuels, which are still an important source of electricity. Renewables indeed overtook fossil fuels for the first time as the EU's main source of power in the year 2020 (renewables represented $38 \%$ of EU electricity vs. $37 \%$ for fossil fuels and $25 \%$ for nuclear) [1,2]; however, in many EU countries, the share of fossil fuels is still very high [1].

Obtaining electricity from fossil fuels releases enormous amounts of greenhouse gases and other pollutants into the atmosphere [3-5], not to mention destroying the landscape in vast spaces. It is estimated that, in 2019, the energy sector was responsible for $77 \%$ of greenhouse gas emissions, followed by agriculture (11\%), industrial processes and product use $(9 \%)$, and waste management $(3 \%)$ [6].

Notably, in 2019, in the EU, households were responsible for $26.3 \%$ of the final energy consumption (understood following the definition of Eurostat Glossary as the total energy consumed by end-users, such as households, industry, agriculture, and transport, among others [7]), and $25 \%$ of this consumption was electricity [8]. Moreover, a large amount of electricity is wasted daily through the unconscious behavior of household members; it is estimated that this may be as much as $35 \%$ of electricity $[9,10]$.

Many studies have indicated that promoting energy saving can significantly reduce the amount of energy wasted (e.g., [11-17]). This is important in the context of pursuing 
the ambitious strategies and goals set out in the Kyoto Protocol (1997), the Paris Agreement (2015), and, most recently, at the COP26 Climate Summit in Glasgow (2021), which, in turn, reduces the risk of dangerous effects of climate destabilization [18,19].

Public communication (or information) campaigns are among the tools for promoting energy saving [17,20-23]. Public communication campaigns can be defined as purposive attempts to disseminate information or change behaviors in audiences within a specified time using various communication activities and featuring media messages in numerous channels to produce benefits to individuals and society [24]. In addition, most energy conservation communication campaigns are aimed at individual changes in consumer behavior by presenting positive behavior patterns and shaping appropriate habits [13,25-27].

Many studies have confirmed that changing human behavior has a large impact on energy saving and environmental sustainability (e.g., $[19,28-36])$. However, they explained that various obstacles increase energy efficiency [37] and proved that traditional media campaigns that promote pro-ecological knowledge and attitudes through simple dissemination of information often do not bring a lasting change in behavior [23,38,39]. Moreover, as these campaigns relied heavily on procedural information, instructions, and "calls" for behavior change, the effectiveness of these approaches could be enhanced by communicating messages that are simple, relevant, tailored, and delivered by reliable and trusted sources $[33,39]$. Therefore, a crucial task in the process of creating a campaign is to design a simple message to effectively reach the average consumer [24,40-45].

It is a beneficial practice to create alternate messages for presentation in media (television, radio, internet, etc.) - most often in the form of social advertising — and pretest them to find the most effective [44]. The proposed messages should consider various motivations for saving electricity by individual consumers in households, as the campaign's effectiveness may depend on it $[46,47]$. Interestingly, these motivations are many $[48,49]$. Saving electricity may be inspired by ecology [50], the desire to reduce expenses [51], interest in the latest technology and new devices, or the influence of activities undertaken by family and friends [34,52].

Pretesting alternative media messages involves using a variety of methods to examine messages among target audience members to find out what works best in achieving the goals of the campaign [44]. The main task of this process is choosing the best message and/or examining what elements should be changed or improved so that the message arouses the greatest involvement of the recipients with the lowest possible emission costs. Increased involvement may contribute to a change in the attitude toward the problem of energy saving and, in turn, lead to a permanent behavior change into the desired one [53].

The research methodology during the pretesting is mostly drawn from a commercial marketing toolkit. It includes both quantitative and qualitative methods [54]. However, it is gradually being more recognized that the results acquired with the use of such methods are not fully trustworthy as the subjects are not always capable of evaluating media messages according to their true feelings [55]. Therefore, the following question arises: What additional research methods should be applied at the stage of testing the media message of a communication campaign so that its effectiveness can be assessed more reliably and/or improved even before its broadcast?

In recent years, to learn about the unconscious opinions of recipients, it has become increasingly common to use the methods of cognitive neuroscience in commercial marketing $[56,57]$. Such methods offer access to data that cannot be acquired when conducting research with the use of conventional methods [58]. This is because people are sometimes unable (or unwilling) to discover their true preferences. Human behavior can be motivated by processes that are unavailable for conscious awareness, and the person's feelings are often undetectable to an interviewer using traditional techniques [55,59].

The benefits of using cognitive neuroscience tools in commercial marketing have led to the occurrence of a new area of science known as neuro-marketing [60-63]. In the field of social marketing, in the study of the effectiveness of public communication campaigns, with a few exceptions (e.g., [64-70]), such methods have not been widely used so far. While the potential 
benefits of using such methods with regard to creating the energy policy are indicated [71], the available literature lacks reports of empirical research into effectiveness of energy-saving campaigns with the help of cognitive neuroscience tools. This study fills this gap.

In this article, we aim to present the procedure of using the methods of cognitive neuroscience in conjunction with a questionnaire to experimentally check the effectiveness of the message on the example of selected electricity-saving communication campaigns.

The remainder of this study is organized as follows: Section 2 focuses on the methods of testing the effectiveness of messages in communication campaigns, with particular emphasis on the methods of cognitive neuroscience. Section 3 describes the experimental research allowing us to achieve the goal of this study. Then, the results of the data analysis obtained during the experiment are presented in Section 4, as well as the possibilities of using them to increase the effectiveness of the message and reduce the costs of emission. Section 5 presents the discussion. Lastly, Section 6 presents the conclusions and limitations, as well as an indication of the direction of future research.

\section{Methods of Testing the Effectiveness of the Media Message}

The effectiveness of a communication campaign, whether it is commercial or social, depends greatly on the communicated message [72]. It is generally believed that an effective message has to gain the attention of the target audience, as well as remain easy to understand and remember without any further explanation [73]. An effective message should involve the recipient's mind and influence their perception, as it can considerably increase the effect of a social campaign. Due to the complexity of the issue, the assessment is most frequently made at five different levels [74]: awareness, engagement, change in behavior, social norm, and wellbeing.

At every level, different indices of the campaign's success can be distinguished. To acquire the significant data at each stage, numerous methods have also been used. A summary of frequently used indicators, with suitable ways of collecting the data, is shown in Table 1.

Table 1. Indicators and measures used in the evaluation of a communication campaign's message effectiveness (source: [75]).

\begin{tabular}{|c|c|c|}
\hline & Indicators & Means of Measurement \\
\hline Awareness & $\begin{array}{l}\text {-Percentage of recipients presenting awareness of } \\
\text { the issue }\end{array}$ & -Audience surveys \\
\hline Engagement & $\begin{array}{l}\text {-Percentage of recipients involved in the debates and } \\
\text { dialogues about the problem } \\
\text {-Percentage of recipients who take action to acquire } \\
\text { supplementary knowledge about the issue }\end{array}$ & $\begin{array}{l}\text {-Audience surveys } \\
\text {-Behavioral data (for example, website hits) }\end{array}$ \\
\hline Change in behavior & $\begin{array}{l}\text {-Percentage of audience members that report } \\
\text { behavior change } \\
\text {-Percentage of recipients for whom modifications of } \\
\text { behavior were noted }\end{array}$ & $\begin{array}{l}\text {-Audience surveys } \\
\text {-Behavioral data (dependent on the type } \\
\text { of campaign) }\end{array}$ \\
\hline Social norm & $\begin{array}{l}\text {-Percentage of recipients showing positive feelings } \\
\text { toward the issue } \\
\text {-Percentage of articles and attitudes favorable to } \\
\text { the campaign } \\
\text {-Legislation introduced on the promoted issue }\end{array}$ & $\begin{array}{l}\text {-Audience surveys } \\
\text {-Observations } \\
\text {-Anecdotal feedback } \\
\text {-Media and policy tracking }\end{array}$ \\
\hline Wellbeing & $\begin{array}{l}\text {-Percentage growth in social outcome } \\
\text {-Percentage growth in environmental outcome }\end{array}$ & $\begin{array}{l}\text {-Epidemiological data } \\
\text {-Environmental data }\end{array}$ \\
\hline
\end{tabular}

In general, on most levels, research procedures used to determine the media message effectiveness may be qualitative and quantitative. The first category is based on words, while the second is based on numbers, which come from counting things occurring in the environment [76]. Qualitative methods (interviews, focus groups, and ethnography) provide a profound understanding of the sense that consumers derive from media messages [77]. However, they also have substantial limitations: they are subjective, difficult to replicate, and not representative of a larger population $[78,79]$. Moreover, conclusions 
greatly depend on the researcher's personal analysis and judgment [80]. Quantitative methods can solve these problems. The frequently used methods in this approach are based on questionnaires [81]. They are easy to disseminate, cost-effective, practical, fast, and scalable; moreover, they allow gaining access to many subjects [82]. Such questionnaires are most often employed when the investigator is trying to measure and evaluate opinions, attitudes, and behaviors [83]. This method can offer a substantial and trustworthy understanding of the population [84], but people frequently do not say exactly what they are actually thinking or doing [85]. Therefore, the information collected can be biased or inaccurate [86] because it is hard for people to reconstruct and clarify their thoughts and feelings [87], or they cannot articulate an explanation for their preferences [88,89]. Furthermore, regarding the abovementioned methods, various studies have shown that various preference elicitation methods may result in distinct replies $[85,90]$. In addition, it was also suggested that the researcher's persona has a great impact on what the respondent remembers and their personal experience [91,92]. Taking that into account, there is a need to apply other research techniques. Since it is assumed that $95 \%$ of human decision making is unconscious [55,61], neurological tools can overcome the fundamental limitations of conventional qualitative research methods, such as focus groups and self-reports, and identify the driving forces behind a personal decision to become involved in campaigns $[93,94]$. An overview of cognitive neuroscience techniques can be found in many publications $[95,96]$.

Neuro-marketing researchers have already shown that neural reactions can be more precise predictors of consumer behavior than self-reported replies [97,98]. Neuroscientific methods may help to "complete the picture", as they provide deeper insights into information processing and decision making $[63,99]$. The consumer neuroscience literature suggests that there is a demand for such an approach [100], with neuroscience techniques to be considered as a supplementary technique rather than a substitute for conventional research techniques.

Despite the benefits of using such measures, the key question is in selecting the metrics of media message effectiveness. The examples of neurophysiological measures used to evaluate advertising effectiveness are gathered in Table 2. We focused on studies using electroencephalography (EEG) since it is one of the most popular and cost-effective neuroscience techniques [96]. Interestingly, we also applied it in our study.

Table 2. Examples of EEG measures (source: own elaboration).

\begin{tabular}{|c|c|c|}
\hline Measure & Formula & Description \\
\hline $\begin{array}{l}\text { Attention (theta synchronization, } \\
\text { alpha desynchronization) [101] }\end{array}$ & $\begin{array}{l}\text { Average }_{\text {theta }} \\
\text { Average }_{\text {alpha }}\end{array}$ & $\begin{array}{l}\text { Brain signal shows an increase in theta activity and a } \\
\text { decrease in alpha activity. }\end{array}$ \\
\hline $\begin{array}{l}\text { Frontal asymmetry } \\
\text { (approach-avoidance, interest } \\
\text { index) [102-109] }\end{array}$ & $\begin{array}{l}\text { Average Power } \\
\text { alpha } \\
\text { Averaght,frontal } \\
\text { Power }_{\text {alpha }_{\text {left,frontal }}}\end{array}$ & $\begin{array}{l}\text { Brain activity registered by left-frontal electrodes is } \\
\text { compared with brain activity gathered by the } \\
\text { right-frontal electrodes [102]. }\end{array}$ \\
\hline Memorization index [105] & Average Power theta left,frontal & $\begin{array}{l}\text { The EEG signal is filtered in the theta band, and } \\
\text { left-frontal channels are selected. The spatial average } \\
\text { is computed for these channels [105]. }\end{array}$ \\
\hline Impression index [108] & Memorization $_{\text {theta }}-\eta \times$ Attention $_{\text {alpha }}$ & $\begin{array}{l}\text { The impression relates to the interval in which the } \\
\text { subject is in the status of both good memorization } \\
\text { and high attention [108]. }\end{array}$ \\
\hline Neuroengagement score [109] & $\frac{\text { Area under cortical activity waveform }}{\text { SD }}$ & $\begin{array}{l}\text { The score for an individual is calculated by dividing } \\
\text { the total area under the waveform corresponding to } \\
\text { cortical activity by its standard deviation during } \\
\text { stimulus presentation [109]. }\end{array}$ \\
\hline Pleasantness index [102] & $\begin{array}{l}\text { Global Field Power }{ }_{\text {Right }}(\text { Like/Dislike })- \\
\text { Global Field } \text { Power }_{\text {Left }}(\text { Like/Dislike })\end{array}$ & $\begin{array}{l}\text { The brain activity in the theta and alpha frequencies } \\
\text { registered by the left-frontal electrodes is compared } \\
\text { with the brain activity recorded by the right-frontal } \\
\text { electrodes [102]. }\end{array}$ \\
\hline Reaction times [110] & $\begin{array}{l}\text { Time of reaction - } \\
\text { Time of stimuli presentation }\end{array}$ & $\begin{array}{l}\text { The measure shows how quickly the brain responds } \\
\text { after the presentation of stimuli [110]. }\end{array}$ \\
\hline
\end{tabular}


From the exemplary measures gathered in Table 2, we focused on engagement, as it is also one of the levels on which media message effectiveness is evaluated.

The engagement concept derives from fields including sociology, psychology, and organizational behavior [111]. It is a cognitive state that does not have a rigorous definition in the neuroscience perspective and that we define by "emotionally laden attention" [112].

The traditional methods of engagement research include mostly questionnaires [113], interviews [114], and gathering behavioral data [115]. Some studies have also used EEG to measure engagement. It has been studied in many different settings: gaming [116-118], training [119], news reading [120,121], electronic and mobile health interventions [122], online shopping [123], social media [124,125], and advertising [126,127]. Depending on the context, there are various engagement measures. In this study, we focused on a measure based on biosignals registered in the frontal lobe since it is proven that all higher cognitive processes are executed [62].

In the available literature, we did not find any reports concerning the use of EEG to study the media message effectiveness of energy-saving campaigns. The prospective directions of one neuroimaging method (fMRI) were presented in [71]; however, experiments were not conducted. We believe that experiments with the use of cognitive neuroscience tools can guide the development of effective messaging, detect the impact of individual differences on the decision process, and aid predictions concerning the efficacy of policy interventions. Therefore, in the subsequent sections of this article, we present research performed to assess the media message effectiveness of energy-saving communication campaigns, and we discuss its results.

\section{Materials and Methods}

\subsection{Participants}

Participants in the experiment were recruited via word of mouth. Tests were conducted for a group of 29 persons, which is a common sample size for neuroscience research [128]. Participants were aged from 19 to 51 years. The mean age was $29.38( \pm 10.67)$. All participants (except one person) were right-handed. The sample consisted of 14 women and 15 men. They were employees and students at the University of Szczecin. Informed consent, approved by the local ethics committee, was acquired from each subject after the clarification of the study.

\subsection{Stimuli}

For the experiment, we used two media messages concerning the energy-saving topic. Both were originally broadcast by Polish television in the autumn of 2012. The first was financed by Energa, an energy company, and the second was financed by the Ministry of the Environment (Both advertisements can be found on the internet: https:/ / www.youtube. com/watch?v=K-_CKkYw9NY (accessed on 8 September 2021); https:/ / www.youtube.com/ watch? $\mathrm{v}=\mathrm{sCWj2XQjCyw}$ (accessed on 8 September 2021)).

The Energa campaign, beyond raising awareness about the need for rational use of energy, was aimed at improving the image of the enterprise as the most ecological energy supplier in Poland. The leading roles in the media message were played by pets-cats, dogs, and canaries. They showed how to save energy through simple, everyday activities: switching off unnecessary light or turning off your TV and computer. The frame sequence for this media message is shown in Figure 1. 


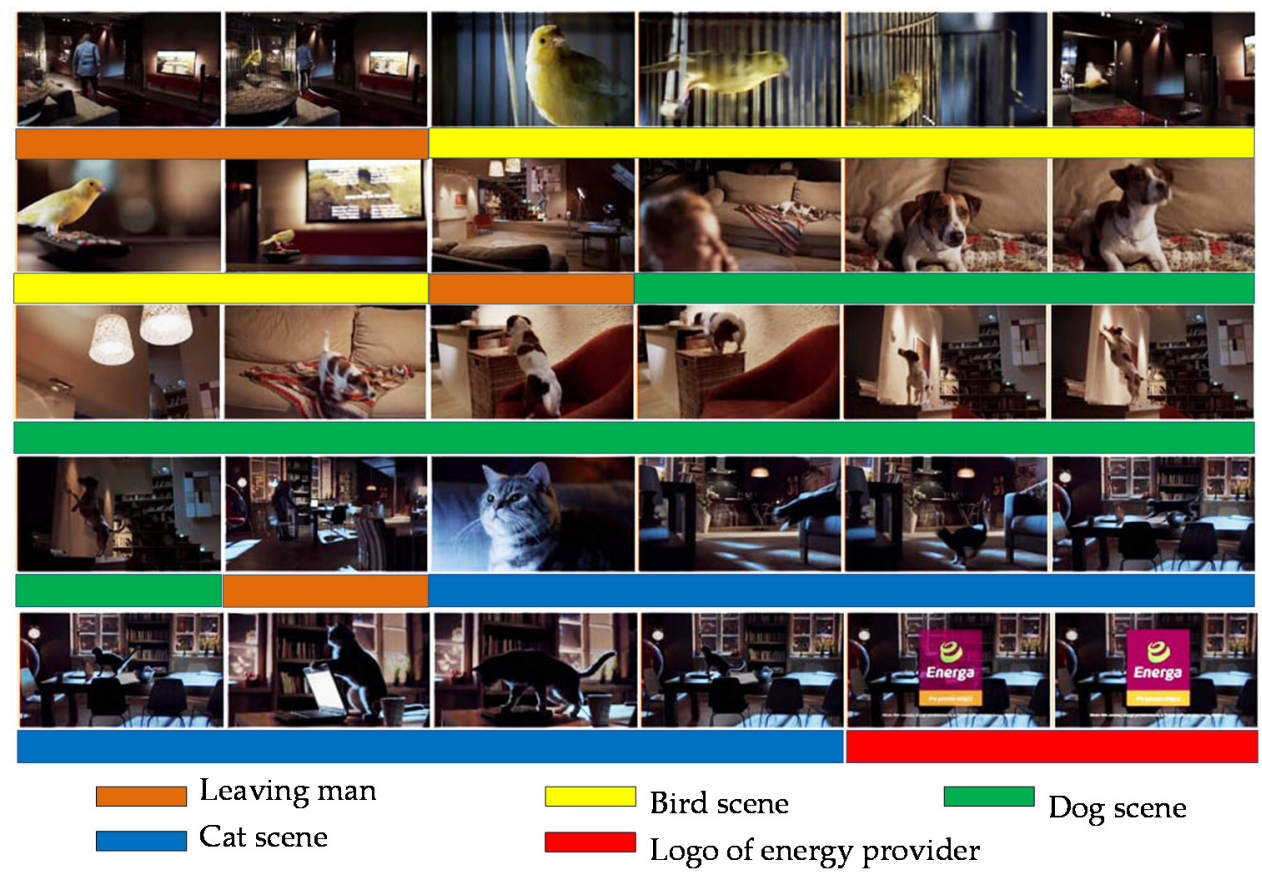

Figure 1. Frame sequence for Energa media message.

The second message used in the experiment was prepared to encourage people to protect the environment and climate through a rational use of energy. This campaign relied on authorities-two famous Polish professors, Jerzy Bralczyk (linguist) and Zbigniew Lew-Starowicz (sexologist). In a humorous and light way, they explained that it is easy to save money and the environment by saving energy in the first place. In addition to their commentary, announcements also showed people presenting desirable behaviors. The slogan for this ad was "turn off power, turn on savings". Figure 2 presents the frame sequence for this media message.

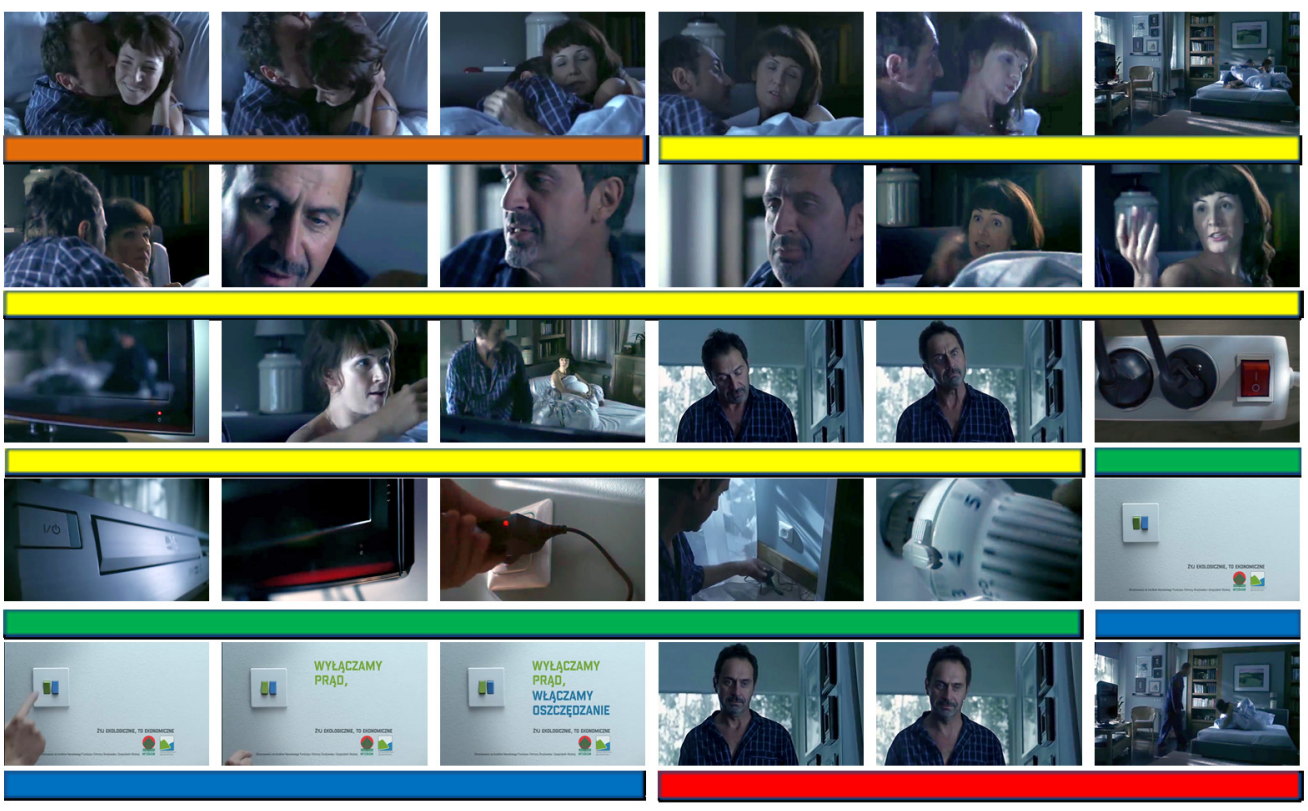

Couple in bed $\square$ Talk about switching off $\square$ Switching off electric appliances Campaign slogan Scene back in bed

Figure 2. Frame sequence for the media message financed by the Ministry of Environment "turn off power, turn on savings". 
Both media messages were chosen for analysis in the experiment because they share some similarities (topic, aim, light and humorous appeal).

\subsection{Procedure}

The experiment involved presenting the stimuli in a laboratory with the use of cognitive neuroscience tools. An outline of the study is shown in Figure 3.

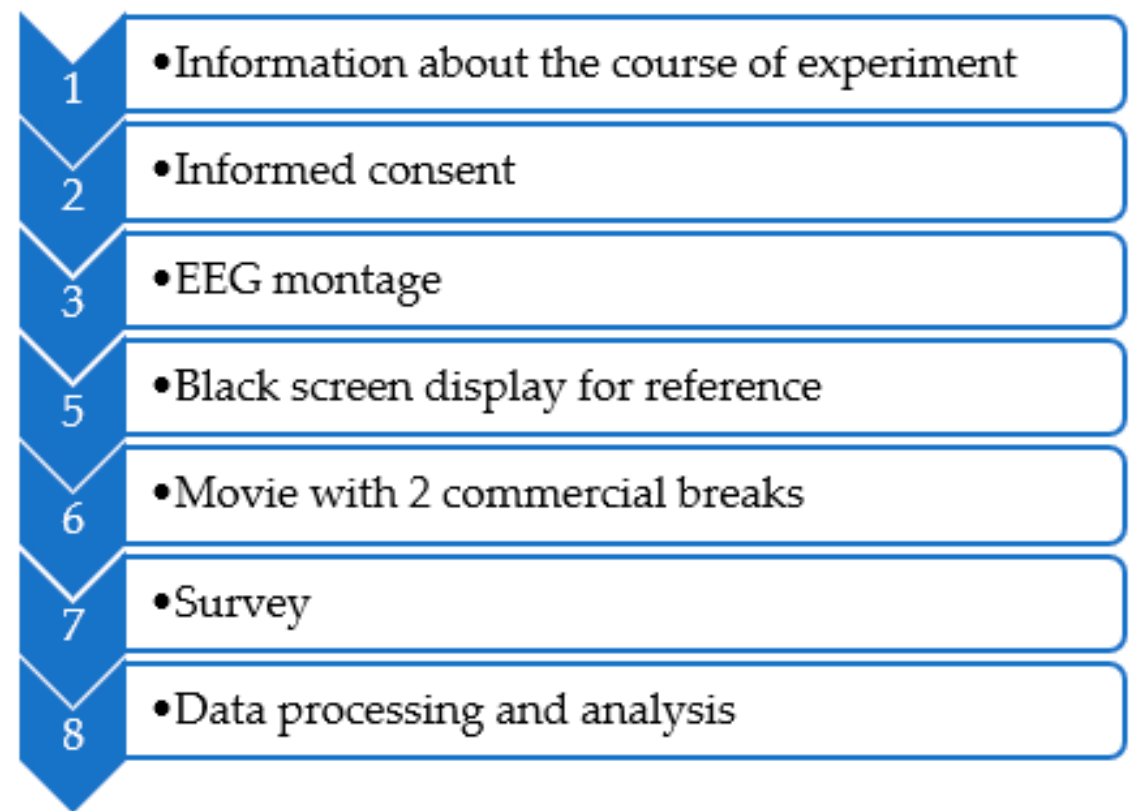

Figure 3. Experimental procedure.

Experimental stimuli were presented using the above procedure. A black image of a triangle rotating around the vertical axis, which was displayed for $30 \mathrm{~s}$, was used to focus the participant's concentration on the computer screen and to record a baseline activity for neurophysiological signals (Figure 4).

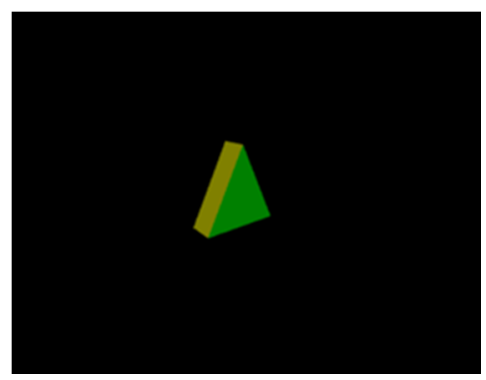

Figure 4. Screen showing a rotating figure.

Subjects who took part in the experiment watched a 30 min movie. It was a popular science documentary with two commercial breaks. Each break was formed by six advertising video clips of $30 \mathrm{~s}$ or $60 \mathrm{~s}$ length. Such commercial interruptions were homogeneous in terms of the quality of all the advertisements presented, which were on air at the time the experiments were performed (HD resolution). Among the commercial ads, two media messages concerning energy saving were placed. During the video, the EEG response was collected from the subjects. After watching, participants took part in a questionnaire regarding the content they had just seen. In this part of experiment, the researcher asked the subjects to spontaneously recall the video clips that they memorized. Then, the experimenter orally listed the series of advertisements presented within the documentary, asking the participants to report which clip they remembered. Successively, the researcher 
presented on a paper the frame sequences of each advertisement shown during the movie. Throughout these two stages, the researcher also showed names and pictures related to advertisements that were not inserted in the commercial break. Finally, the experimenter asked the subjects to give a score between 1 and 10 indicating the level of appreciation they felt during the observation of each remembered ad (1, lowly pleasant; 5 , indifferent; 10 , highly pleasant).

\subsection{Registration and Processing of Neurophysiological Data}

The cerebral activity was recorded with the use of the g.Nautilus device, with a sampling rate of $500 \mathrm{~Hz}$. For the needs of the study, electrodes were installed on the scalp according to the guidelines of the 10-20 system [129]. The recorded EEG signal was subjected to preprocessing, in which the frequency of 49-51 Hz was removed by the bandpass filter using Fourier transform. In European countries, the frequency of electricity in the power grid is $50 \mathrm{~Hz}$ with a certain tolerance allowed. Due to the prevalence of electrically powered devices, sinusoidal disturbances with frequencies of $50 \mathrm{~Hz}$ and their multiples are very common. They arise at the time of both recording and transmitting analog signals. In the case of EEG recording, due to the high sensitivity of measuring devices, there is a high probability of their occurrence. Hence, it is necessary to filter the frequency from the recorded signal within a small range of $50 \mathrm{~Hz}$. Interference multiples of $50 \mathrm{~Hz}$ are much weaker, and their frequency significantly differs from the frequency range used in the EEG signal analyses conducted in this article. Hence, it was not necessary to remove them. Long-term fluctuations were also removed from the EEG signal. This deletion was performed using the local mean value. For each signal sample, the mean value at plus or minus half a second from its position was calculated. This mean value was then subtracted from the sample. The resulting signal had long-term fluctuations removed.

In addition to the recorded signal, events related to the start and end of sequentially played clips and film fragments were recorded. On this basis, the EEG signal was divided into fragments assigned to individual media messages.

EEG registrations for each person were subjected to an artefact removal procedure. ICA (independent component analysis) decomposition of the signal was performed [130]. After such decomposition, typically one or two components of the signal were related to artefacts. These components were removed from the signal, thereby cleaning the signal. This procedure was performed separately for each of the test persons, as the number of components containing artefacts differed across individuals, and they were not always the same.

The next step was to determine the individual alpha frequency (IAF) [131], which was the basis for the determination of the frequency range $\theta$. To determine the IAF continuous wavelet transformation, the Morse wavelet family was used [132]. In the frequency range $(7.5-12.5 \mathrm{~Hz})$ of the wavelet transformation spectrum, the IAF frequency was calculated using the weighted average, where the weights for frequencies were determined as the ratio of the energy of a given frequency component to the energy of the entire frequency band (7.5-12.5 Hz). The searched frequency range $\theta$ was designated as [IAF-6; IAF-2].

\subsection{Measures}

According to the recorded data, the engagement index was determined. This index was proposed by Yamada [116]. It analyzes theta frontal lobe activity, indicating increased attention. The value of this index was determined as a function of the global field power (GFP) for the frequency range $\theta$. For this purpose, the continuous wavelet transformation and the Morse wavelet family were reused. The spectrum of the wavelet transformation was determined, and then the frequency range $\theta$ was removed for the purpose of further analysis. For this range, the mean spectral energy of the electrodes placed on the frontal lobe at each instant of time was calculated. The designated values were the values of the engagement index.

The determined indices of engagement for individual subjects are incomparable due to the different conductivity of the electrodes resulting from different skin properties. To allow 
comparability, they were standardized. For this purpose, the mean value and standard deviation were determined for all calculated engagement indices for each respondent. The corresponding mean value was then subtracted from the exposure indices and divided by the corresponding standard deviation.

\section{Results}

For analysis purposes, the media messages were divided into fragments. The "turn off power, turn on savings" clip was divided into five fragments: "couple in bed" (0-3 s), "talk about switching off the TV" (3-16 s), "switching off electric appliances" (16-23 s), "campaign slogan" (23-27 s), and "scene back in bed" (27-30 s). Energa's clip was also divided into five fragments: "leaving man" (0-2 s; 9-11 s; 19-21 s), "bird scene" (2-9 s), "dog scene" (11-19 s), "cat scene" (21-26 s), and "logo of energy provider" (26-29 s).

The mean value and standard deviation were calculated for each fragment. The determined values for the "turn off power, turn on savings" media message are presented in Figure 5. The mean value of zero denotes the average engagement in the entire study. All mean values of the normalized engagement index were below zero. This means that the ad attracted less attention than most of the material presented. The high standard deviation for the "switching off electric appliances" suggests means that, for this fragment of the clip, the degree of engagement varied the most.

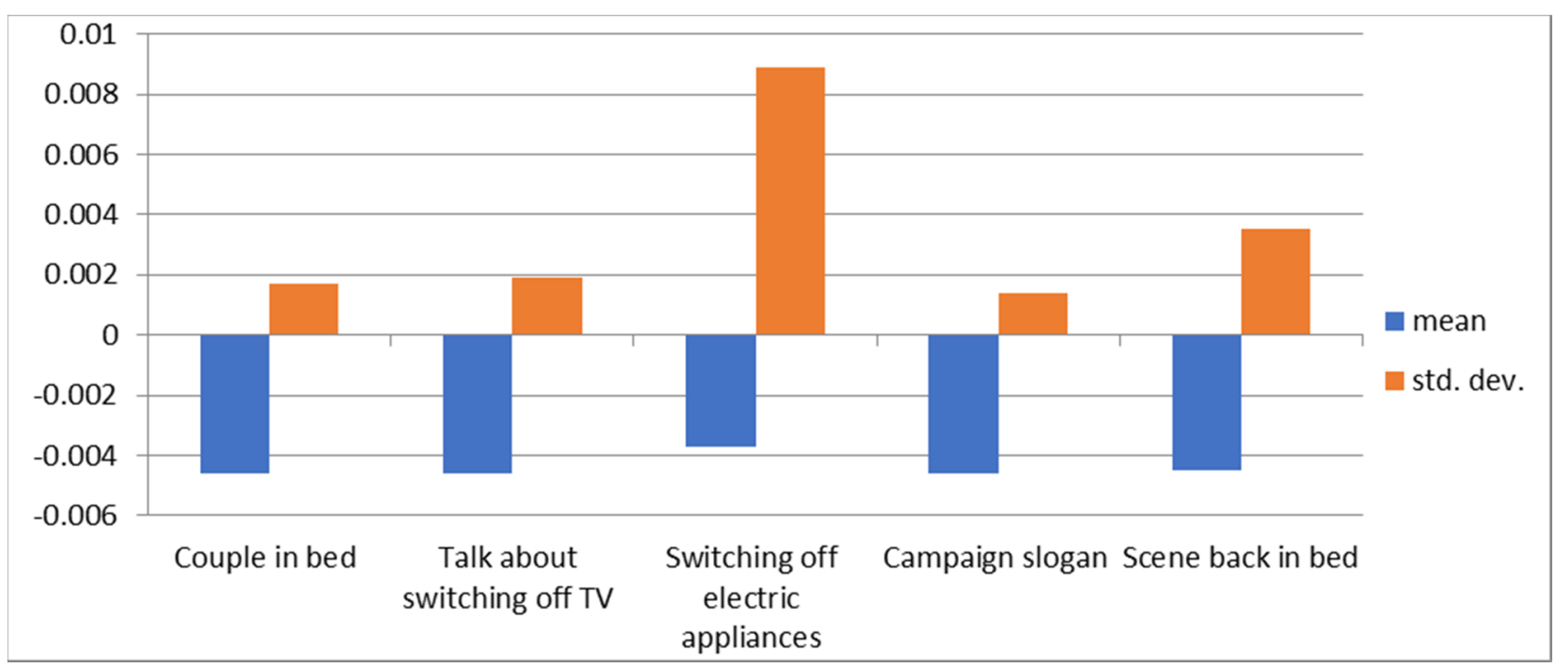

Figure 5. Average values and standard deviations of the normalized index of engagement for the "turn off power, turn on savings" media message.

As additional analysis, the perception of this advertisement was also checked depending on the sex of the respondent. The obtained results indicate that the presented message attracted the attention of men and women to a different extent. Figure 6 shows that men were generally less engaged. 


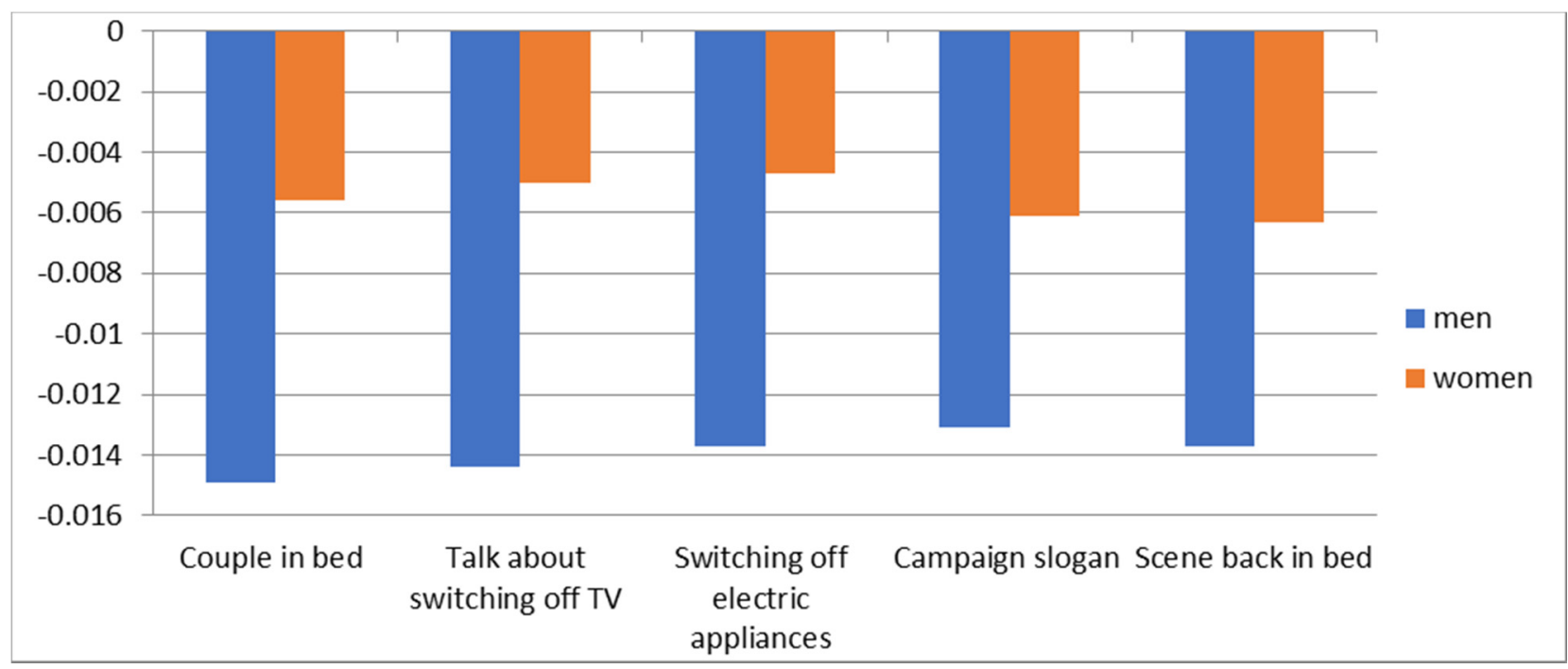

Figure 6. Average values of the normalized male and female engagement indices for the "turn off power, turn on savings" media message.

For men, the largest discrepancy in the value of engagement was visible for the "campaign slogan", while, for women, the scenes for "talk about switching off" and "switching off electric appliances" stood out (Figure 7). Considering the values of the engagement index, it can be concluded that the "turn off power, turn on savings ad" did not attract the attention of potential recipients.

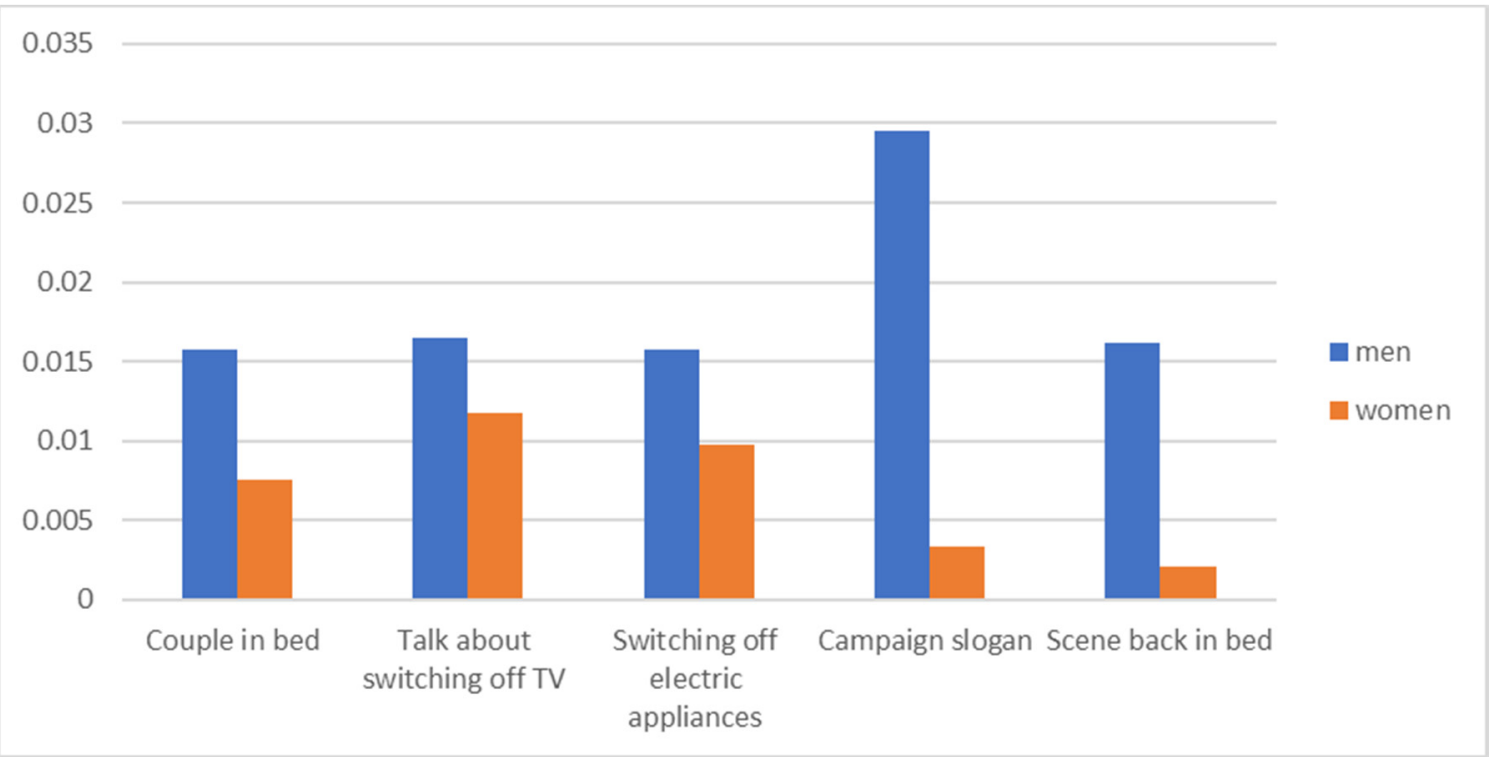

Figure 7. Standard deviations of the normalized male and female engagement indices for the "turn off power, turn on savings" media message.

The determined mean values and standard deviations of the normalized engagement index for the Energa media message are shown in Figure 8. All mean values, except for the "bird scene" fragment, were above the mean value obtained for the entire presented audiovisual material, which should be considered a good result, as it means that the message aroused commitment among the participants of the experiment. A high value of standard deviations for most fragments suggests that the degree of attention grabbed varied, especially for the "dog scene". 


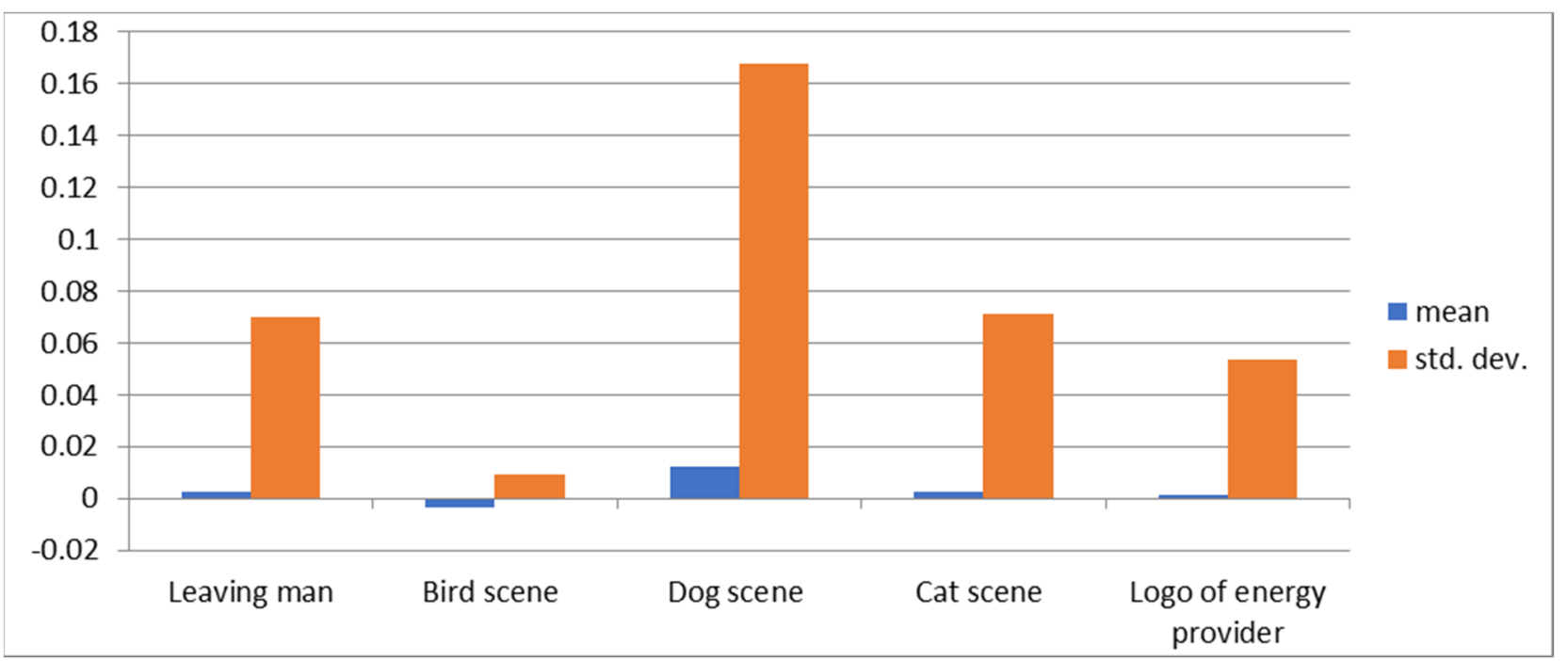

Figure 8. Average values and standard deviations of the normalized index of engagement for the Energa media message.

Considering the values of the standardized engagement index in relation to women and men, it can be noted that the message definitely attracted the attention of women more. The only exception was "leaving man", which attracted more male attention. In the case of women, the "dog scene" attracted the most attention, but their interest was also attracted by "leaving man", "cat scene", and "logo of energy provider" (Figure 9).

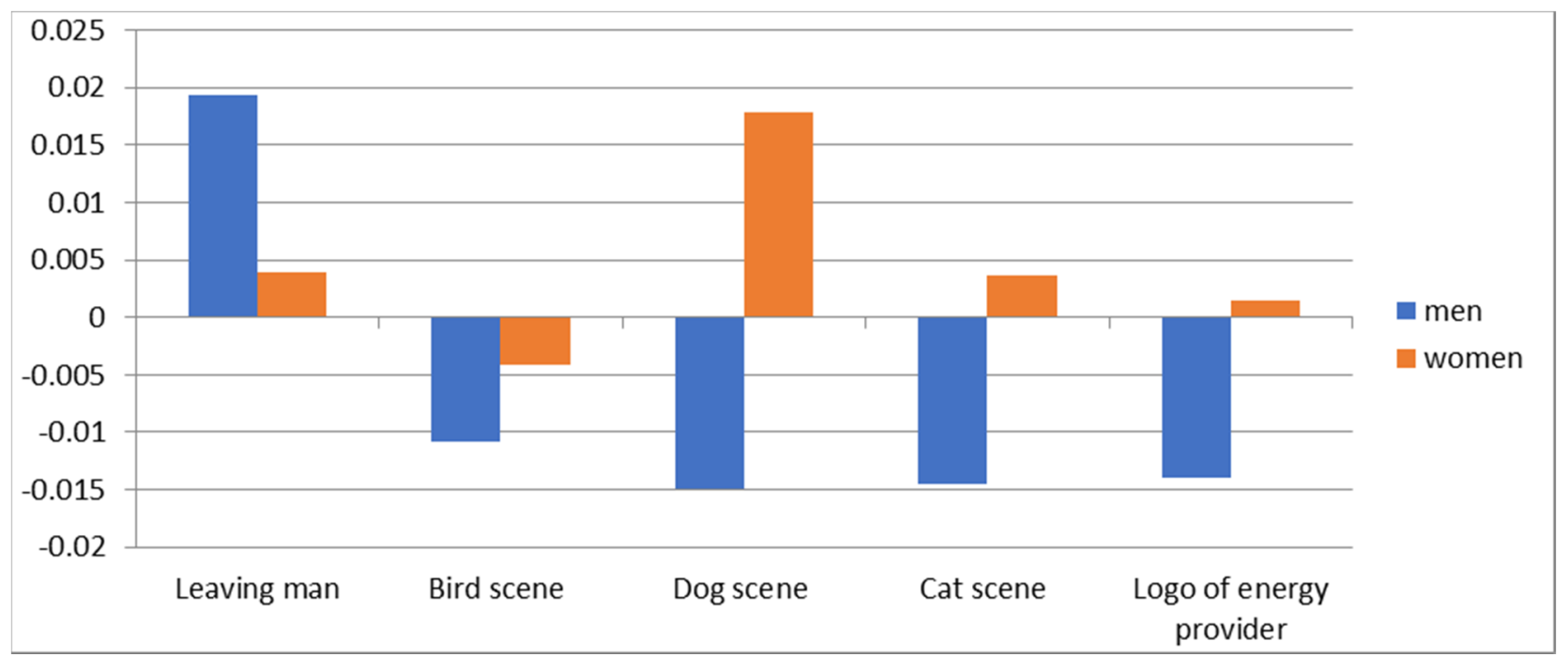

Figure 9. Average values of the normalized male and female engagement indices for the Energa media message.

For men, the most diverse results were obtained for "leaving man", while, for women, the most diverse results were obtained for the "dog scene" (Figure 10). Summarizing the results, it can be said that the advertisement was mainly directed at women, and the "bird scene" attracted the least attention. Therefore, it could be replaced or deleted. The most eye-catching was the "dog scene". What is important is that the advertisement as a whole attracted so much attention that "logo of energy provider" also obtained values of the standardized engagement index higher than the average material presented to the respondents, which should be considered a good result. 


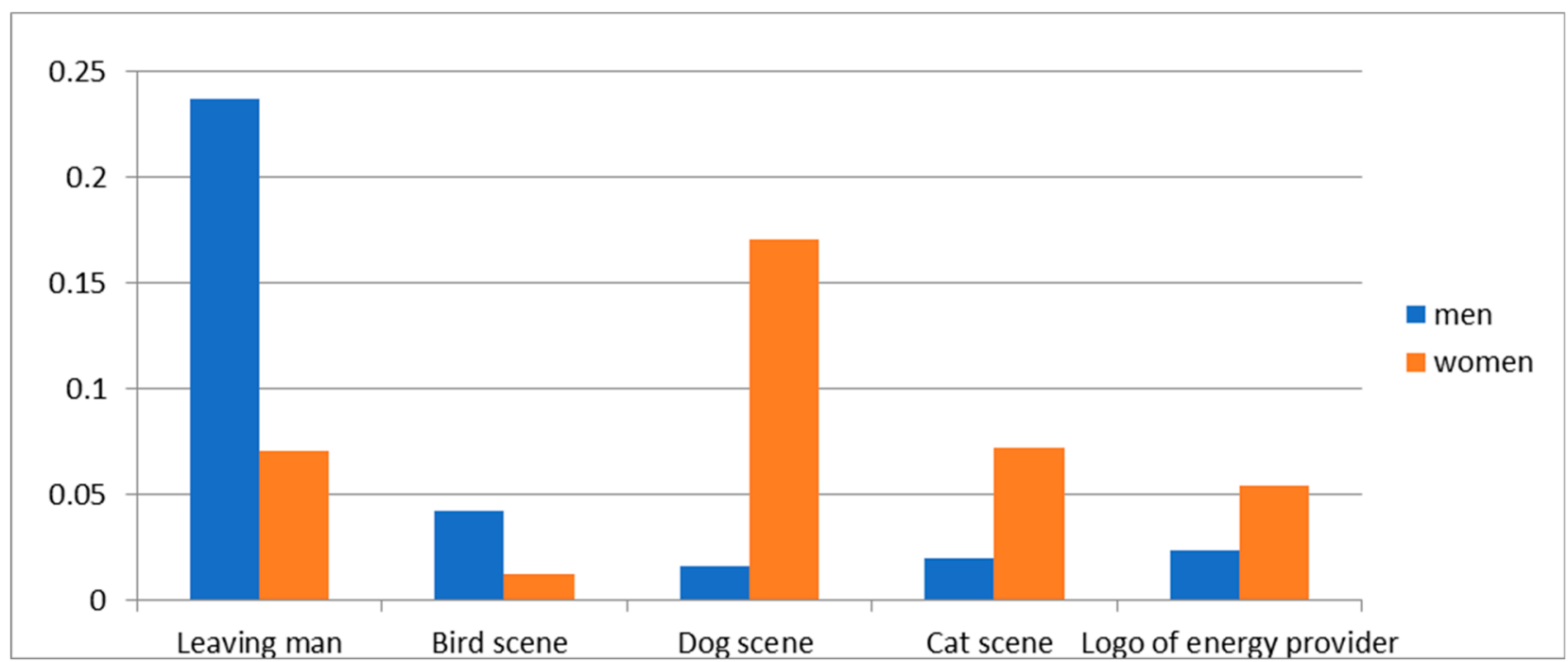

Figure 10. Standard deviations of the normalized male and female engagement indices for Energa media message.

The presentation of the experimental stimulus was followed by a questionnaire that was created to collect the responses about the advertisements' recall and appreciation. This part of the research was conducted to check whether there would be a difference between the conscious replies of the subjects and their psychophysiological reactions. As mentioned before, for the questionnaire, participants responded to three questions concerning spontaneous and aided recall of advertisements. They had an opportunity to express their appreciation for the ads in terms of a 1-10 scale assessment.

When it came to spontaneous recall, only four people out of $29(13.8 \%)$ remembered the examined ads (i.e., both of them; there were no cases where a person memorized only one advertisement of interest). Considering the sex of respondents, it turned out that $75 \%$ of those who remembered both messages without any aid were men. The participants who spontaneously recalled these spots memorized mostly the topic of the social campaign (saving energy). They did not paid attention to who was responsible for emitting the ads (only one person mentioned Energa) or to the slogan used for promoting the idea. When it came to the recall of the plot, they referred only to the "turn off power, turn on saving" advertisement in a more detailed manner (two out of four subjects remembered a couple discussing the need for saving). Aided recall with the use of stills taken from the PSAs gave the same results: both ads were recalled by 19 persons out of $29(65 \%)-11$ of them were women, which means that almost $76 \%$ of female respondents that took part in the experiment remembered the message after receiving some visual cues.

The appreciation assessment given by the subjects was normalized (a Z-score was computed for every person), and the average value for the whole group of participants was calculated. Conducted $t$-tests revealed no significant difference in the scores for Energa $(\mathrm{M}=0.0683 ; \mathrm{S}=1.0407)$ and for "turn off $\ldots$ " $(\mathrm{M}=-0.1315 ; \mathrm{S}=0.9405)$ advertisements $(t=0.3744, p=0.7103)$. Considering the assessment of messages depending on the sex of respondents, we determined that there were also no significant differences between women and men. Results of performed tests are summarized in Table 3. 
Table 3. Results of $t$-test for the message assessment in women and men (source: own elaboration).

\begin{tabular}{|c|c|c|c|c|}
\hline & \multicolumn{2}{|c|}{ Energa } & \multicolumn{2}{|c|}{ Turn off ... } \\
\hline & Women & Men & Women & Men \\
\hline Mean & 0.1175 & 0.0007 & -0.3581 & 0.1801 \\
\hline Standard deviation & 1.0244 & 1.1299 & 0.8293 & 1.0491 \\
\hline $\mathrm{t}$ & \multicolumn{2}{|c|}{0.2349} & \multicolumn{2}{|c|}{-1.2506} \\
\hline$p$ & \multicolumn{2}{|c|}{0.8171} & \multicolumn{2}{|c|}{0.2280} \\
\hline
\end{tabular}

\section{Discussion}

The experiment conducted in this study aimed to assess the media message effectiveness of energy-saving communication campaigns. The research was conducted to obtain results that could be used to increase the effectiveness of the media message and to reduce the cost of its broadcasting. We assessed both media messages with the use of traditional research methods (questionnaires) and with a cognitive neuroscience technique (EEG). Recorded brain activity was used to calculate the neurometric index of engagement, which was understood as emotionally laden attention.

Our calculations showed that, regarding engagement, both media messages generated different results. The Energa clip evoked involvement that was greater than the whole audiovisual material shown to the participants; the values of the neurometric were positive. The outcomes for the second video, "turn off power, turn on savings" were negative. This means that viewers were not engaged while watching it, thereby potentially decreasing the effectiveness of this message.

The results showed that, on the subconscious level, Energa's message was assessed better than "turn off power, turn on savings", as it evoked more emotional attention. On this basis, it can be stated that the Energa clip is more effective as a media message promoting energy saving. Considering this media message, we can also state that various scenes induced different levels of engagement. The greatest index values could be observed for the "dog scene", while the lowest values were recorded for the "bird scene". This result can allow us to shorten the media message to reduce the cost of its emission. The aired version of the clip should include only the scenes that evoked the greatest emotional attention.

Additionally, we also decided to conduct analyses that considered women and men separately. For both media messages, it turned out that men generally showed less engagement than women. This was more evident in the case of the Energa media message. This suggests the potential of creating two versions of this media message: the first dedicated to women and the second dedicated to men. In its present form, this clip was more effective when watched by women. However, considering the high standard deviation of engagement index observed for different scenes, it would be recommended to conduct further research on female audiences to find the differences in preference to better profile the media message. Such profiling can be used to decide when to broadcast the message. A study conducted in the United Kingdom showed that genres deeply connected with female audiences are reality TV, talent shows, game/quiz/panel/chat shows, and soap operas [133]. Airing clips created for women before, after, and during these kinds of TV programs can be beneficial in terms of increasing the effectiveness and cost efficiency of media messages.

However, it is worth noting that the results of the conducted survey measuring the assessment of media messages did not show that women appreciated the given stimuli more than men. The difference between the mean scores for both messages was not statistically significant. Moreover, on the conscious level, measured by the recall in the questionnaires, neither media message was successful. Therefore, they cannot be considered effective, at least not in the group that was examined in the research. However, these results cannot be easily generalized to the whole target audience. When compared to the subconscious results obtained, thanks to the EEG recordings, it can be assumed that, in the case of the 
"turn off power, turn on savings" message, the lack of engagement observed in the theta band of brain activity could explain the poor recall noted in surveys. Engagement results for media messages presented by the Energa Company (Gdańsk, Poland), on the other hand, showed that, on the subconscious level, this clip evoked much more involvement than can be expected on the basis of questionnaires and recall. In this case, we can suppose that cognitive neuroscience techniques allowed us to identify inconsistency between the conscious and subconscious judgment of this media message. However, to confirm this result and to explain its cause, we would need to conduct more detailed research.

\section{Conclusions}

The benefits of using methods of cognitive neuroscience in media messages assessment arise from the certain nature of communication campaigns. They require both message memorization and understanding the importance of the promoted behavior. The emergence of such phenomena is possible to grasp using cognitive neuroscience techniques. Such methods have proven their utility in evaluating the effectiveness of media messages more reliably than questionnaires alone. However, these kinds of tools also have limitations. Conducting experiments registering neurophysiological data involves technical abilities and skills. Furthermore, the sense of registered signals may be hard to interpret [56]. Despite these limitations, it remains a promising direction for further research, especially concerning the pretesting of various media messages in communication campaigns. Our research showed benefits that can be obtained with the help of neuroscience and by synergizing traditional research methods with neuroscientific methods to experimentally check the effectiveness of the message of two electricity-saving communication campaigns. The key results of this study indicated that merging conscious and subconscious reactions to media messages allows us to gain new knowledge that can be used in the future to improve the communication campaign effectiveness.

It can be recommended to use the procedure presented in the article by the creators of electricity-saving communication campaigns to prepare a new media message from scratch and pretest various variants in order to select the most effective one. Applying the proposed approach may contribute to the achievement of energy policy objectives at both the local and the global level.

The direction for future studies would be to conduct experiments with more neurometrics proposed in the literature and to make an attempt to aggregate different neuro-indices into a single measure, triangulating its results with questionnaire outcomes.

Author Contributions: Conceptualization, M.Ł. and A.B.; methodology, M.Ł., A.B. and M.B.; software, M.B. and A.B.; validation, M.Ł. and A.B.; formal analysis, M.B. and A.B.; investigation, M.Ł., M.B. and A.B.; resources, M.Ł. and A.B.; data curation, M.B. and A.B.; writing-original draft preparation, M.Ł. and A.B.; writing-review and editing, M.Ł. and A.B.; visualization, M.Ł. and A.B.; supervision, M.Ł.; project administration, A.B.; funding acquisition, A.B. All authors have read and agreed to the published version of the manuscript.

Funding: This research was financed with the National Science Center funds allocated according to the decision DEC-2016/21/B/HS4/03036.

Institutional Review Board Statement: The study was conducted according to the guidelines of the Declaration of Helsinki, and approved by the Bioethics Committees at Regional Chamber of Physicians in Szczecin (protocol code: 02/KB/VII/2020, date: 18 June 2020).

Informed Consent Statement: Informed consent was obtained from all subjects involved in the study.

Data Availability Statement: Not applicable.

Conflicts of Interest: The authors declare no conflict of interest. The funders had no role in the design of the study; in the collection, analyses, or interpretation of data; in the writing of the manuscript, or in the decision to publish the results. 


\section{References}

1. Redl, C.; Hein, F.; Buck, M.; Graichen, P.; Jones, D. The European Power Sector in 2020: Up-to-Date Analysis on the Electricity Transition; Agora Energiewende and Ember: Berlin, Germany, 2021.

2. European Commission, Directorate-General for Energy Progress on Competitiveness of Clean Energy Technologies. Report from the Commission to the European Parliament and the Council. COM(2021) 952 Final; European Commission: Brussels, Belgium, 2021.

3. Climate Change 2021: The Physical Science Basis (WG1); Masson-Delmotte, V.; Zhai, P.; Pirani, A.; Connors, S.L.; Péan, C.; Chen, Y. (Eds.) Cambridge University Press: Cambridge, UK, 2021.

4. Höök, M.; Tang, X. Depletion of Fossil Fuels and Anthropogenic Climate Change-A Review. Energy Policy 2013, 52, 797-809. [CrossRef]

5. Delannoy, L.; Longaretti, P.-Y.; Murphy, D.J.; Prados, E. Peak Oil and the Low-Carbon Energy Transition: A Net-Energy Perspective. Appl. Energy 2021, 304, 117843. [CrossRef]

6. European Environmental Agency. EEA Greenhouse Gases-Data Viewer. Available online: https://www.eea.europa.eu/data-andmaps / data/data-viewers/greenhouse-gases-viewer (accessed on 28 December 2021).

7. Eurostat Statistics Explained. Available online: https://ec.europa.eu/eurostat/statistics-explained/ (accessed on 20 December 2021).

8. Eurostat Energy Consumption in Households. Available online: https:/ / ec.europa.eu/eurostat/statistics-explained/index.php? title=Energy_consumption_in_households (accessed on 15 December 2021).

9. Campbell, U. The Biggest Sources of Residential Energy Consumption. Available online: https://www.connect4climate.org/ article/biggest-sources-residential-energy-consumption (accessed on 30 December 2021).

10. Desjardins, J. Visualizing U.S. Energy Consumption in One Chart. Available online: https://www.visualcapitalist.com/ visualizing-u-s-energy-consumption-one-chart/ (accessed on 29 December 2021).

11. Song, Q.; Li, J.; Duan, H.; Yu, D.; Wang, Z. Towards to Sustainable Energy-Efficient City: A Case Study of Macau. Renew. Sustain. Energy Rev. 2017, 75, 504-514. [CrossRef]

12. Khan, I.; Halder, P.K. Electrical Energy Conservation through Human Behavior Change: Perspective in Bangladesh. Int. J. Renew. Energy Res. 2015, 6, 43-52.

13. Kim, K.-H. Overview on Public Benefit Campaigns to Promote Energy Conservation and Energy Efficiency. In The United Nations Forum on Energy Efficiency and Energy Security: Taking Collaborative Action on Mitigation Climate Change; United Nations: Seoul, Korea, 2007.

14. Piccolo, L.S.G.; Alani, H. Strategies and Tools to Raise Energy Awareness Collectively. In Proceedings of the Behave 2016-4th European Conference on Behaviour and Energy Efficiency, Coimbra, Portugal, 8-9 September 2016; University of Coimbra: Coimbra, Portugal, 2016.

15. Carrico, A.R.; Vandenbergh, M.P.; Stern, P.C.; Dietz, T. US Climate Policy Needs Behavioural Science. Nat. Clim. Chang. 2015, 5, 177-179. [CrossRef]

16. Rai, V.; Henry, A.D. Agent-Based Modelling of Consumer Energy Choices. Nat. Clim. Chang. 2016, 6, 556-562. [CrossRef]

17. Rivas, S.; Cuniberti, B.; Bertoldi, P. Effective Information Measures to Promote Energy Use Reduction in EU Member States; JRC Science Hub: Brussels, Belgium; European Union: Brussels, Belgium, 2016; ISBN 978-92-79-59815-9.

18. Bernard, L.; Semmler, W.; Hansen, J.E. Environment and Development Challenges. In The Oxford Handbook of the Macroeconomics of Global Warming; Bernard, L., Semmler, W., Eds.; Oxford University Press: Oxford, UK, 2015; ISBN 978-0-19-985697-8.

19. Bohdanowicz, Z.; Łopaciuk-Gonczaryk, B.; Kowalski, J.; Biele, C. Households' Electrical Energy Conservation and Management: An Ecological Break-Through, or the Same Old Consumption-Growth Path? Energies 2021, 14, 6829. [CrossRef]

20. Steg, L. Promoting Household Energy Conservation. Energy Policy 2008, 36, 4449-4453. [CrossRef]

21. Gerster, A.; Andor, M.A.; Peters, J. Information Campaigns for Residential Energy Conservation; Ruhr Economic Papers; RWI-LeibnizInstitut für Wirtschaftsforschung: Essen, Germany; Ruhr-University Bochum: Bochum, Germany; TU Dortmund University: Dortmund, Germany; University of Duisburg-Essen: Duisburg, Germany, 2020; ISBN 978-3-96973-008-9.

22. Farrow, K.; Grolleau, G.; Mzoughi, N. Less Is More in Energy Conservation and Efficiency Messaging. Energy Policy 2018, 122, 1-6. [CrossRef]

23. Abrahamse, W.; Steg, L.; Vlek, C.; Rothengatter, T. A Review of Intervention Studies Aimed at Household Energy Conservation. J. Environ. Psychol. 2005, 25, 273-291. [CrossRef]

24. Rice, R.E.; Atkin, C.K. Public Communication Campaigns; SAGE Publications, Inc.: London, UK, 2013; ISBN 978-1-4129-8770-7.

25. Csobod, É.; Grätz, M.; Szuppinger, P. Overview and Analysis of Public Awareness Raising Strategies and Actions on Energy Savings, INTENSE/Deliverable 6.1/WP6/Year 2009; Baltic Environmental Forum: Riga, Latvia, 2009.

26. Fernandez, M.; Piccolo, L.; Maynard, D.; Wippoo, M.; Meili, C.; Alani, H. Pro-Environmental Campaigns via Social Media: Analysing Awareness and Behaviour Patterns. J. Web Sci. 2017, 3, 1-15. [CrossRef]

27. Keller, S.; Otjen, A.J.; McNally, M.; Wilkinson, T.J.; Dockery, B.; Leonard, J.; Southworth, H. Improving Awareness of Energy Conservation: Rocky Mountain City. JEET 2021, 1, 4-19. [CrossRef]

28. Revell, K. Estimating the Environmental Impact of Home Energy Visits and Extent of Behaviour Change. Energy Policy 2014, 73, 461-470. [CrossRef]

29. Karlin, B.; Davis, N.; Sanguinetti, A.; Gamble, K.; Kirkby, D.; Stokols, D. Dimensions of Conservation: Exploring Differences among Energy Behaviors. Environ. Behav. 2014, 46, 423-452. [CrossRef]

30. Owens, S.; Driffill, L. How to Change Attitudes and Behaviours in the Context of Energy. Energy Policy 2008, 36, 4412-4418. [CrossRef] 
31. Wood, G.; Newborough, M. Energy-Use Information Transfer for Intelligent Homes: Enabling Energy Conservation with Central and Local Displays. Energy Build. 2007, 39, 495-503. [CrossRef]

32. Chatterton, T. An Introduction to Thinking about 'Energy Behaviour': A Multi-Model Approach; Department of Energy and Climate Change: London, UK, 2011.

33. Wilson, C.; Dowlatabadi, H. Models of Decision Making and Residential Energy Use. Annu. Rev. Environ. Resour. 2007, 32, 169-203. [CrossRef]

34. Allcott, H.; Mullainathan, S. Behavior and Energy Policy. Science 2010, 327, 1204-1205. [CrossRef]

35. Jones, R.V.; Fuertes, A.; Lomas, K.J. The Socio-Economic, Dwelling and Appliance Related Factors Affecting Electricity Consumption in Domestic Buildings. Renew. Sustain. Energy Rev. 2015, 43, 901-917. [CrossRef]

36. Gottwalt, S.; Garttner, J.; Schmeck, H.; Weinhardt, C. Modeling and Valuation of Residential Demand Flexibility for Renewable Energy Integration. IEEE Trans. Smart Grid 2017, 8, 2565-2574. [CrossRef]

37. Reddy, A.K.N. Barriers to Improvements in Energy Efficiency. Energy Policy 1991, 19, 953-961. [CrossRef]

38. Schultz, P.W. Strategies for Promoting Proenvironmental Behavior: Lots of Tools but Few Instructions. Eur. Psychol. 2014, 19, 107-117. [CrossRef]

39. Frederiks, E.R.; Stenner, K.; Hobman, E.V. Household Energy Use: Applying Behavioural Economics to Understand Consumer Decision-Making and Behaviour. Renew. Sustain. Energy Rev. 2015, 41, 1385-1394. [CrossRef]

40. Social Marketing for Public Health: Global Trends and Success Stories; Cheng, H.; Kotler, P.; Lee, N. (Eds.) Jones and Bartlett: Sudbury, MA, USA, 2011; ISBN 978-0-7637-5797-7.

41. Information Campaigns: Balancing Social Values and Social Change; Salmon, C.T. (Ed.) Sage Annual Reviews of Communication Research; Sage Publications: Newbury Park, CA, USA, 1989; ISBN 978-0-8039-3218-0.

42. French, J.; Blair-Stevens, C. Key Concepts and Principles of Social Marketing. In Social Marketing and Public Health: Theory and Practice; French, J., Blair-Stevens, C., McVey, D., Merritt, R., Eds.; Oxford University Press: Oxford, UK, 2010.

43. Norberg, P.A.; Marcos, E. Planning the Social Marketing Campaign. In Handbook of Persuasion and Social Marketing; Stewart, D., Ed.; Praeger: Santa Barbara, CA, USA, 2015.

44. Weinreich, N.K. Hands-on Social Marketing: A Step-by-Step Guide to Designing Change for Good; SAGE Publications, Inc.: Thousand Oaks, CA, USA, 2011; ISBN 978-1-4129-5369-6.

45. Lee, N.; Kotler, P. Social Marketing: Behavior Change for Social Good, 6th ed.; SAGE Publications: Los Angeles, CA, USA, 2020; ISBN 978-1-5443-5149-0.

46. Steg, L.; Shwom, R.; Dietz, T. What Drives Energy Consumers?: Engaging People in a Sustainable Energy Transition. IEEE Power Energy Mag. 2018, 16, 20-28. [CrossRef]

47. Abrahamse, W.; Steg, L. How Do Socio-Demographic and Psychological Factors Relate to Households' Direct and Indirect Energy Use and Savings? J. Econ. Psychol. 2009, 30, 711-720. [CrossRef]

48. Parrish, B.; Heptonstall, P.; Gross, R.; Sovacool, B.K. A Systematic Review of Motivations, Enablers and Barriers for Consumer Engagement with Residential Demand Response. Energy Policy 2020, 138, 111221. [CrossRef]

49. Sony, M.; Mekoth, N. A Qualitative Study on Electricity Energy-Saving Behaviour. MEQ 2018, 29, 961-977. [CrossRef]

50. Pandey, D.; Agrawal, M.; Pandey, J.S. Carbon Footprint: Current Methods of Estimation. Environ. Monit. Assess. 2011, 178, 135-160. [CrossRef]

51. Van den Broek, K.L.; Walker, I. Exploring the Perceptions of Drivers of Energy Behaviour. Energy Policy 2019, 129, 1297-1305. [CrossRef]

52. Gołęiowska, B.; Bartczak, A.; Czajkowski, M. Energy Demand Management and Social Norms. Energies 2020, 13, 3779. [CrossRef]

53. Baldinger, A.L.; Cook, W.A. Ad Testing. In Handbook of Marketing Research; Grover, R., Vriens, M., Eds.; Sage Publications: London, UK, 2006; pp. 487-505.

54. Smith, S.M.; Albaum, G.S. An Introduction to Marketing Research; Qualtrics: Seattle, WA, USA, 2010.

55. Zaltman, G. How Customers Think: Essential Insights into the Mind of the Market; Harvard Business School Press: Boston, MA, USA, 2003; ISBN 978-1-57851-826-5.

56. Lindstrom, M. Buyology: Truth and Lies about Why We Buy, 1st ed.; Broadway Books: New York, NY, USA, 2010; ISBN 978-0-385-52389-9.

57. Ohme, R.; Matukin, M.; Pacula-Lesniak, B. Biometric Measures for Interactive Advertising Research. J. Interact. Advert. 2011, 11, 60-72. [CrossRef]

58. Ariely, D.; Berns, G.S. Neuromarketing: The Hope and Hype of Neuroimaging in Business. Nat. Rev. Neurosci. 2010, 11, $284-292$. [CrossRef] [PubMed]

59. Calvert, G.A.; Brammer, M.J. Predicting Consumer Behavior: Using Novel Mind-Reading Approaches. IEEE Pulse 2012 , 3, 38-41. [CrossRef] [PubMed]

60. Fisher, C.E.; Chin, L.; Klitzman, R. Defining Neuromarketing: Practices and Professional Challenges. Harv. Rev. Psychiatry 2010, 18, 230-237. [CrossRef]

61. Żurawicki, L. Neuromarketing: Exploring the Brain of the Consumer; Springer: Berlin/Heidelberg, Germany; London, UK, 2010; ISBN 978-3-540-77828-8.

62. Morin, C. Neuromarketing: The New Science of Consumer Behavior. Society 2011, 48, 131-135. [CrossRef]

63. Agarwal, S.; Dutta, T. Neuromarketing and Consumer Neuroscience: Current Understanding and the Way Forward. Decision 2015, 42, 457-462. [CrossRef] 
64. Zelinková, J.; Shaw, D.J.; Mareček, R.; Mikl, M.; Urbánek, T.; Havlíčková, D.; Zámečník, P.; Haitová, P.; Brázdil, M. An Evaluation of Traffic-Awareness Campaign Videos: Empathy Induction Is Associated with Brain Function within Superior Temporal Sulcus. Behav. Brain Funct. 2014, 10, 27. [CrossRef]

65. Mauri, M.; Ciceri, A.; Songa, G.; Sirca, F.; Onorati, F.; Russo, V. The Effects of Social Communication: A Research Study on Neuroscientific Techniques Application. In Proceedings of the Measuring Behavior 2014-9th International Conference on Methods and Techniques in Behavioral Research, Wageningen, The Netherlands, 27-29 August 2014; Spink, A., van den Broek, E.L., Loijens, L., Wołoszynowska-Fraser, M., Noldus, L., Eds.; Noldus Information Technology: Wageningen, The Netherlands, 2014.

66. Falk, E.B.; O’Donnell, M.B.; Tompson, S.; Gonzalez, R.; Dal Cin, S.; Strecher, V.; Cummings, K.M.; An, L. Functional Brain Imaging Predicts Public Health Campaign Success. Soc. Cogn. Affect. Neurosci. 2016, 11, 204-214. [CrossRef]

67. Borawska, A.; Duda, J.; Biercewicz, K. Best Practices of Neurophysiological Data Collection for Media Message Evaluation in Social Campaigns. Procedia Comput. Sci. 2021, 192, 4017-4026. [CrossRef]

68. Piwowarski, M.; Nermend, K. Cognitive Neuroscience in the Design Process of Social Advertising. Procedia Comput. Sci. 2020, 176, 2959-2968. [CrossRef]

69. Piwowarski, M. Cognitive Neuroscience Techniques in Examining the Effectiveness of Social Advertisements. In Neuroeconomic and Behavioral Aspects of Decision Making; Nermend, K., Łatuszyńska, M., Eds.; Springer Proceedings in Business and Economics; Springer International Publishing: Cham, Switzerland, 2017; pp. 341-352, ISBN 978-3-319-62937-7.

70. Borawska, A.; Borawski, M.; Piwowarski, M. Techniques of Cognitive Neuroscience in the Assessment and Measurement of Environmental Public Service Announcements Effectiveness. In Proceedings of the 23rd World Multi-Conference on Systemics, Cybernetics and Informatics, Orlando, FL, USA, 6-9 July 2019; International Institute of Informatics and Systemics: Winter Garden, FL, USA, 2019; Volume 1, pp. 110-115.

71. Sawe, N. Adapting Neuroeconomics for Environmental and Energy Policy. Behav. Public Policy 2019, 3, 17-36. [CrossRef]

72. Wymer, W. Developing More Effective Social Marketing Strategies. J. Soc. Mark. 2011, 1, 17-31. [CrossRef]

73. Raab, M.; Rocha, J. Campaigns to End Violence against Women and Girls; UN Women: New York, NY, USA, 2011.

74. Donovan, R.J.; Henley, N. Social Marketing: Principles and Practice; IP Communications: Melbourne, Australia, 2003; ISBN 978-0-9578617-5-6.

75. Varcoe, J. Assessing the Effectiveness of Social Marketing; ESOMAR®—The World Association of Research Professionals: Lincoln, NE, USA, 2004.

76. Basil, M.D. Research and Evaluation in Social Marketing. In Social Marketing in Action; Basil, D.Z., Diaz-Meneses, G., Basil, M.D., Eds.; Springer International Publishing: Cham, Switzerland, 2019; pp. 45-57, ISBN 978-3-030-13019-0.

77. Andrews, J.C.; Shimp, T.A. Advertising, Promotion and Other Aspects of Integrated Marketing Communication, 10th ed.; Cengage: Mason, OH, USA, 2017; ISBN 978-1-337-28265-9.

78. Daymon, C.; Holloway, I. Qualitative Research Methods in Public Relations and Marketing Communications, 2nd ed.; Routledge: New York, NY, USA, 2011; ISBN 978-0-415-47117-6.

79. Hakim, A.; Levy, D.J. A Gateway to Consumers' Minds: Achievements, Caveats, and Prospects of Electroencephalography-based Prediction in Neuromarketing. WIREs Cogn. Sci. 2019, 10, e1485. [CrossRef] [PubMed]

80. Smithson, J. Using and Analysing Focus Groups: Limitations and Possibilities. Int. J. Soc. Res. Methodol. 2000, 3, 103-119. [CrossRef]

81. Gordon, R.; Ciorciari, J. Social Marketing Research and Cognitive Neuroscience. In Formative Research in Social Marketing; Kubacki, K., Rundle-Thiele, S., Eds.; Springer: Singapore, 2017; pp. 145-163, ISBN 978-981-10-1827-5.

82. Wilkinson, D.; Birmingham, P. Using Research Instruments: A Guide for Researchers; RoutledgeFalmer: London, UK, 2003; ISBN 978-0-203-42299-1.

83. French, J.; Gordon, R. Strategic Social Marketing: For Behaviour and Social Change, 2nd ed.; SAGE: Thousand Oaks, CA, USA, 2019; ISBN 978-1-5264-4604-6.

84. Basil, M. Survey for Formative Research. In Formative Research in Social Marketing; Kubacki, K., Rundle-Thiele, S., Eds.; Springer: Singapore, 2017; pp. 251-263, ISBN 978-981-10-1827-5.

85. Neeley, S.M.; Cronley, M.L. When Research Participants Don't Tell It like It Is: Pinpointing the Effects of Social Desirability Bias Using Self vs. In direct-Questioning. In NA-Advances in Consumer Research; Kahn, B.E., Luce, M.L., Eds.; Association for Consumer Research: Valdosta, GA, USA, 2004; Volume 31, pp. 432-433.

86. Cummings, R.G.; Harrison, G.W.; Rutström, E.E. Homegrown Values and Hypothetical Surveys: Is the Dichotomous Choice Approach Incentive-Compatible? Am. Econ. Rev. 1995, 85, 260-266.

87. Bagozzi, R.P. The Role of Psychophysiology in Consumer Research. In Handbook of Consumer Behavior; Robertson, T.S., Kassarjian, H.H., Eds.; Prentice-Hall: Upper Saddle River, NJ, USA, 1991; pp. 124-161.

88. List, J.A.; Gallet, C.A. What Experimental Protocol Influence Disparities between Actual and Hypothetical Stated Values? Environ Resour. Econ. 2001, 20, 241-254. [CrossRef]

89. Vecchiato, G.; Astolfi, L.; De Vico Fallani, F.; Toppi, J.; Aloise, F.; Bez, F.; Wei, D.; Kong, W.; Dai, J.; Cincotti, F.; et al. On the Use of EEG or MEG Brain Imaging Tools in Neuromarketing Research. Comput. Intell. Neurosci. 2011, 2011, 643489. [CrossRef]

90. Johansson, P.; Hall, L.; Sikström, S.; Tärning, B.; Lind, A. How Something Can Be Said about Telling More than We Can Know: On Choice Blindness and Introspection. Conscious. Cogn. 2006, 15, 673-692. [CrossRef]

91. McDonald, C. Is Your Advertising Working? A Guide to Evaluating Campaign Performance; World Advertising Research Center: Henley-on-Thames, UK; Oxfordshire, UK; Washington, DC, USA, 2003; ISBN 978-1-84116-139-6. 
92. Vecchiato, G.; Di Flumeri, G.; Maglione, A.G.; Cherubino, P.; Kong, W.; Trettel, A.; Babiloni, F. An Electroencephalographic Peak Density Function to Detect Memorization during the Observation of TV Commercials. In Proceedings of the 2014 36th Annual International Conference of the IEEE Engineering in Medicine and Biology Society, Chicago, IL, USA, 26-30 August 2014; IEEE: Chicago, IL, USA, 2014; pp. 6969-6972.

93. Micu, A.C.; Plummer, J.T. Measurable Emotions: How Television Ads Really Work: Patterns of Reactions to Commercials Can Demonstrate Advertising Effectiveness. JAR 2010, 50, 137-153. [CrossRef]

94. Varan, D.; Lang, A.; Barwise, P.; Weber, R.; Bellman, S. How Reliable Are Neuromarketers' Measures of Advertising Effectiveness? Data from Ongoing Research Holds No Common Truth among Vendors. JAR 2015, 55, 176-191. [CrossRef]

95. Kable, J.W. The Cognitive Neuroscience Toolkit for the Neuroeconomist: A Functional Overview. J. Neurosci. Psychol. Econ. 2011, 4, 63-84. [CrossRef] [PubMed]

96. Harris, J.M.; Ciorciari, J.; Gountas, J. Consumer Neuroscience for Marketing Researchers. J. Consum. Behav. 2018, 17, 239-252. [CrossRef]

97. Berns, G.S.; Moore, S.E. A Neural Predictor of Cultural Popularity. J. Consum. Psychol. 2012, 22, 154-160. [CrossRef]

98. Falk, E.B.; Berkman, E.T.; Mann, T.; Harrison, B.; Lieberman, M.D. Predicting Persuasion-Induced Behavior Change from the Brain. J. Neurosci. 2010, 30, 8421-8424. [CrossRef] [PubMed]

99. Falk, E.B.; Berkman, E.T.; Lieberman, M.D. From Neural Responses to Population Behavior: Neural Focus Group Predicts Population-Level Media Effects. Psychol. Sci. 2012, 23, 439-445. [CrossRef] [PubMed]

100. Lim, W.M. Demystifying Neuromarketing. J. Bus. Res. 2018, 91, 205-220. [CrossRef]

101. Harris, J.M.; Ciorciari, J.; Gountas, J. Consumer Neuroscience and Digital/Social Media Health/Social Cause Advertisement Effectiveness. Behav. Sci. 2019, 9, 42. [CrossRef] [PubMed]

102. Guixeres, J.; Bigné, E.; Ausín Azofra, J.M.; Alcañiz Raya, M.; Colomer Granero, A.; Fuentes Hurtado, F.; Naranjo Ornedo, V. Consumer Neuroscience-Based Metrics Predict Recall, Liking and Viewing Rates in Online Advertising. Front. Psychol. 2017, 8, 1808. [CrossRef] [PubMed]

103. Matukin, M.; Ohme, R.; Boshoff, C. EEG-Based Measures versus Panel Ratings: Predicting Social-Media Based Behavioral Responses to Super Bowl Ads. J. Adv. Res. 2016, 56, 205. [CrossRef]

104. Venkatraman, V.; Dimoka, A.; Pavlou, P.A.; Vo, K.; Hampton, W.; Bollinger, B.; Hershfield, H.E.; Ishihara, M.; Winer, R.S. Predicting Advertising Success beyond Traditional Measures: New Insights from Neurophysiological Methods and Market Response Modeling. J. Mark. Res. 2015, 52, 436-452. [CrossRef]

105. Vecchiato, G.; Maglione, A.G.; Cherubino, P.; Wasikowska, B.; Wawrzyniak, A.; Latuszynska, A.; Latuszynska, M.; Nermend, K.; Graziani, I.; Leucci, M.R.; et al. Neurophysiological Tools to Investigate Consumer's Gender Differences during the Observation of TV Commercials. Comput. Math. Methods Med. 2014, 2014, 1-12. [CrossRef] [PubMed]

106. Briesemeister, B.B.; Tamm, S.; Heine, A.; Jacobs, A.M. Approach the Good, Withdraw from the Bad-A Review on Frontal Alpha Asymmetry Measures in Applied Psychological Research. Psychology 2013, 4, 261-267. [CrossRef]

107. Touchette, B.; Lee, S.-E. Measuring Neural Responses to Apparel Product Attractiveness: An Application of Frontal Asymmetry Theory. Cloth. Text. Res. J. 2017, 35, 3-15. [CrossRef]

108. Kong, W.; Zhao, X.; Hu, S.; Vecchiato, G.; Babiloni, F. Electronic Evaluation for Video Commercials by Impression Index. Cogn. Neurodyn. 2013, 7, 531-535. [CrossRef] [PubMed]

109. Deitz, G.D.; Royne, M.B.; Peasley, M.C.; Huang, J. “Coco” EEG-Based Measures versus Panel Ratings: Predicting Social-Media Based Behavioral Responses to Super Bowl Ads. J. Adv. Res. 2016, 56, 217. [CrossRef]

110. Alonso Dos Santos, M.; Calabuig Moreno, F. Assessing the Effectiveness of Sponsorship Messaging: Measuring the Impact of Congruence through Electroencephalogram. IJSMS 2018, 19, 25-40. [CrossRef]

111. Brodie, R.J.; Hollebeek, L.D.; Jurić, B.; Ilić, A. Customer Engagement: Conceptual Domain, Fundamental Propositions, and Implications for Research. J. Serv. Res. 2011, 14, 252-271. [CrossRef]

112. Dmochowski, J.P.; Sajda, P.; Dias, J.; Parra, L.C. Correlated Components of Ongoing EEG Point to Emotionally Laden Attention-A Possible Marker of Engagement? Front. Hum. Neurosci. 2012, 6, 112. [CrossRef] [PubMed]

113. Hollebeek, L.D.; Glynn, M.S.; Brodie, R.J. Consumer Brand Engagement in Social Media: Conceptualization, Scale Development and Validation. J. Interact. Mark. 2014, 28, 149-165. [CrossRef]

114. Hollebeek, L. Exploring Customer Brand Engagement: Definition and Themes. J. Strateg. Mark. 2011, 19, 555-573. [CrossRef]

115. Strecher, V.; McClure, J.; Alexander, G.; Chakraborty, B.; Nair, V.; Konkel, J.; Greene, S.; Couper, M.; Carlier, C.; Wiese, C.; et al. The Role of Engagement in a Tailored Web-Based Smoking Cessation Program: Randomized Controlled Trial. J. Med. Internet Res. 2008, 10, e36. [CrossRef] [PubMed]

116. Yamada, F. Frontal Midline Theta Rhythm and Eyeblinking Activity during a VDT Task and a Video Game: Useful Tools for Psychophysiology in Ergonomics. Ergonomics 1998, 41, 678-688. [CrossRef] [PubMed]

117. McMahan, T.; Parberry, I.; Parsons, T.D. Evaluating Player Task Engagement and Arousal Using Electroencephalography. Procedia Manuf. 2015, 3, 2303-2310. [CrossRef]

118. Vourvopoulos, A.; Bermudez i Badia, S.; Liarokapis, F. EEG Correlates of Video Game Experience and User Profile in MotorImagery-Based Brain-Computer Interaction. Vis. Comput. 2017, 33, 533-546. [CrossRef]

119. Stikic, M.; Berka, C.; Levendowski, D.J.; Rubio, R.F.; Tan, V.; Korszen, S.; Barba, D.; Wurzer, D. Modeling Temporal Sequences of Cognitive State Changes Based on a Combination of EEG-Engagement, EEG-Workload, and Heart Rate Metrics. Front. Neurosci. 2014, 8, 342. [CrossRef] [PubMed] 
120. Pope, A.T.; Bogart, E.H.; Bartolome, D.S. Biocybernetic System Evaluates Indices of Operator Engagement in Automated Task. Biol. Psychol. 1995, 40, 187-195. [CrossRef]

121. Arapakis, I.; Barreda-Angeles, M.; Pereda-Banos, A. Interest as a Proxy of Engagement in News Reading: Spectral and Entropy Analyses of EEG Activity Patterns. IEEE Trans. Affect. Comput. 2019, 10, 100-114. [CrossRef]

122. Short, C.E.; DeSmet, A.; Woods, C.; Williams, S.L.; Maher, C.; Middelweerd, A.; Müller, A.M.; Wark, P.A.; Vandelanotte, C.; Poppe, L.; et al. Measuring Engagement in EHealth and MHealth Behavior Change Interventions: Viewpoint of Methodologies. J. Med. Internet Res. 2018, 20, e292. [CrossRef] [PubMed]

123. Dulabh, M.; Vazquez, D.; Ryding, D.; Casson, A. Measuring Consumer Engagement in the Brain to Online Interactive Shopping Environments. In Augmented Reality and Virtual Reality; Jung, T., Tom Dieck, M.C., Eds.; Progress in IS; Springer International Publishing: Cham, Switzerland, 2018; pp. 145-165, ISBN 978-3-319-64026-6.

124. Marques, I.R.; Casais, B.; Camilleri, M.A. The Effect of Macrocelebrity and Microinfluencer Endorsements on Consumer-Brand Engagement in Instagram. In Strategic Corporate Communication in the Digital Age; Camilleri, M.A., Ed.; Emerald Publishing Limited: Bingley, UK, 2021; pp. 131-143, ISBN 978-1-80071-265-2.

125. Pynta, P.; Seixas, S.A.S.; Nield, G.E.; Hier, J.; Millward, E.; Silberstein, R.B. The Power of Social Television: Can Social Media Build Viewer Engagement?: A New Approach to Brain Imaging of Viewer Immersion. JAR 2014, 54, 71-80. [CrossRef]

126. Balasubramanian, S.; Gullapuram, S.S.; Shukla, A. Engagement Estimation in Advertisement Videos with EEG. arXiv 2018, arXiv:1812.03364.

127. Clark, K.R.; Leslie, K.R.; Garcia-Garcia, M.; Tullman, M.L. How Advertisers Can Keep Mobile Users Engaged and Reduce Video-Ad Blocking: Best Practices for Video-Ad Placement and Delivery Based on Consumer Neuroscience Measures. JAR 2018, 58, 311-325. [CrossRef]

128. Plassmann, H.; Venkatraman, V.; Huettel, S.; Yoon, C. Consumer Neuroscience: Applications, Challenges, and Possible Solutions. J. Mark. Res. 2015, 52, 427-435. [CrossRef]

129. Klem, G.H.; Lüders, H.O.; Jasper, H.H.; Elger, C. The Ten-Twenty Electrode System of the International Federation. The International Federation of Clinical Neurophysiology. Electroencephalogr. Clin. Neurophysiol. Suppl. 1999, 52, 3-6. [PubMed]

130. Stone, J.V. Independent Component Analysis: An Introduction. Trends Cogn. Sci. 2002, 6, 59-64. [CrossRef]

131. Klimesch, W. EEG Alpha and Theta Oscillations Reflect Cognitive and Memory Performance: A Review and Analysis. Brain Res. Rev. 1999, 29, 169-195. [CrossRef]

132. Borawski, M.; Biercewicz, K.; Duda, J. Determination of the Inaccuracies of Calculated EEG Indices. Sensors 2020, 20, 5715. [CrossRef]

133. Redfern, N. Age, Gender and Television in the United Kingdom. J. Pop. Telev. 2015, 3, 57-73. [CrossRef] 